\title{
Critical Factors for Environmental Performance Assessment (EPA) \\ in Hong Kong Construction Industry
}

Vivian Wing-Yan Tam ${ }^{1 *}$, Chi-Ming. Tam ${ }^{2}$, Kenneth Tai-Wing Yiu ${ }^{3}$ and Sai-On Cheung ${ }^{4}$

Abstract: With the rise in the public concern on environmental protection, more construction firms start to apply environmental management for their construction activities. As a result, Environmental Management Systems (EMS) have been implemented in construction. However, to improve the construction environment in Hong Kong, Environmental Performance Assessment (EPA) has been designed for reviewing, monitoring, checking and evaluating environmental performance. A list of evaluation factors for EPA are identified and grouped into seven major factors: management and training; air and noise; auditing; waste and water; cost-saving on resources; energy; and regulation. The results from a survey highlight that the most important evaluation factor is management and training and the least significant results is regulation. A voluntary approach has been promoted instead of the traditional mandatory system. Furthermore, three case studies are used to test the reliability with seven groups of evaluation factors in measuring the environmental performance for construction. The results from the case study analysis proved the effectiveness of the developed environmental performance assessment. Therefore, the developed environmental performance assessment can benefit the construction industry and help to achieve continuous improvement on environmental performance.

Keywords: Environmental performance assessment, factor analysis, Hong Kong

\footnotetext{
1* Correspondence author, Lecturer, Griffith School of Engineering, Griffith University, PMB 50 Gold Coast Mail Centre, Queensland 9726, Australia. Email: v.tam@griffith.edu.au.

${ }^{2}$ Professor, Department of Building \& Construction, City University of Hong Kong, 83 Tat Chee Avenue, Kowloon, Hong Kong

${ }^{3}$ Instructor, Department of Building \& Construction, City University of Hong Kong, 83 Tat Chee Avenue, Kowloon, Hong Kong.

${ }^{4}$ Associate Professor, Department of Building \& Construction, City University of Hong Kong, 83 Tat Chee Avenue, Kowloon, Hong Kong.
} 


\section{Introduction}

Environment is the surrounding in which an organisation operates, including air, water, land, natural resources, humans and their interrelation. Thousands of non-compliance and complaints are recorded yearly and the worst is a rising trend in the number of noncompliance cases and complaints (EPD, 2004). The environment in this context extends from an organisation to the global system. Nowadays, pollution problems arisen from Hong Kong construction industry have not successfully been controlled. Environmental impacts of buildings over the entire life cycle process have been recognized as a serious problem for the construction industry (Polster et al., 1996; Morledge and Jackson, 2001), which presents considerable challenges for improvements. Environmental management in construction has become a critical issue in recent decades (Shen and Tam, 2002; Tam et al., 2001). Regrettably, the sense of environmental protection remains weak in the Hong Kong construction industry.

The Hong Kong government has launched the green manager scheme and eco-business awards in 1995 and 1999 respectively. Each governmental department is appointed a green manager for managing environmental performance in the green manager scheme; whereas the Hong Kong eco-business awards are granted to organizations demonstrating a strong commitment to environmental protection (EPD, 2001). However, the assessment of environmental protection for each organizational achievement has not been strongly supported in the construction industry. This paper focuses on: i) identifying a number of factors affecting environmental performance in an organization for Environmental Performance Assessment (EPA); ii) analyzing the evaluation factors and grouping them by factor analysis; iii) examining the order of importance of evaluation factors in EPA as perceived by construction professionals and researchers based upon on a developed list of 
evaluation factors; and iv) verifying the effectiveness of EPA by implementing it to three case studies.

\section{Relationship between an Environmental Management System (EMS) and Environmental Performance Assessment (EPA)}

An Environmental Management System (EMS) is used to establish environmental policies, objectives, and targets. Environmental Performance Assessment (EPA) is defined as a management tool used to set specific, measurable goals and objectives to various stages of environmental management processes, including planning, implementation, monitoring, measurement and management review. The use of EPA is a process of measurement and analysis of factors, which have direct and indirect impacts on the environment (Wathey and O’Reilly, 2000). The EPA helps to improve the environmental performance by providing information on achievement in environmental policies, objectives, targets, actions, and responsibilities in organizations and provide continuous information on the implementation and operation of the programme (Wathey and O’Reilly, 2000). This system can also measure, analyse and assess the organizational environmental performance (Crawley et al., 1999; Kuhre, 1998; Ren ,2000 Tam et al., 2002a; Tse, 2001; Wu et al., 2000). Reports generated from EPA can identify ways to prevent pollution, which assists the identification and establishment of an environmental programme in an organization. Furthermore, it helps personnel familiarize with organizational policies, procedures and programmes in environmental achievements (Bennett and James, 1999b; CGS, 2001; Kuhre, 1998). All environmental related policies, objectives, targets, procedures and practices that are oriented toward reducing environmental impacts should be considered in the EPA system (Jasch, 2000; Kuhre, 1998; Meyer, 2001). Kuhre (1998) pointed out that EPA could act as a starting point to establish the existing objectives and targets, and could be used to measure the 
progress of the work programmes towards achieving the aims of those environmental polices. Although EPA is one of the elements in EMS, EPA can be used to assess the environmental performance in any situations. For long-term business, EPA alone can be used to support the objective of continuous improvement in the environmental performance (Meyer, 2001). Due to the long-established conservative culture, the applications of EPA remain weak in Hong Kong construction industry. The industry shall be more adaptive to accept management functions and values in the existing system. An overview of EPA is shown in Figure 1 (Kuhre, 1998).

$<$ Figure $1>$

\section{The Evaluation Factors}

The EPA process should be equipped with a universal set of evaluation factors for continuous assessment of the organizational performance against the specified factors. Gottinger (1993) identified six guidelines for the selection of factors of EPA: i) The selection should be systematic so that the results are repeatable. That is, it should be possible for different people to follow the procedures and obtain similar results; ii) The process should not be so complicated that only a few people are able to use it or to understand the results; iii) The process should be able to generate answers within a reasonable length of time; iv) The process should be capable of providing useful information on a reasonable evaluation budget; v) The system should conform to the various legal and administrative requirements to which it pertains; and vi) The method should be capable of taking into account all of the factors relevant to the decision it is intended to aid. However, simple units of measures are preferred; hence a set of standard evaluation factors shall be used to show the trends or cause-and-effect relationships. These factors should condense information that raises people awareness in understanding the environment, and measures the progress towards the established goal. The 
evaluation factors can offer an overview of the relevant performance of the construction organization and highlight the problem areas. The advantage of having some concrete figures from EPA with various evaluation factors is that they can make the definition and pursuit of environmental targets controllable and verifiable, and identify the potential monetary benefits (Jasch, 2000). By monitoring the indicators, regular evaluation and target control can be exercised since they can highlight any adverse trends in the process of environmental control. A list of evaluation factors from literature reviews was showed in Table 1.

$<$ Table 1>

To support the application of EPA system, it is necessary to develop a list of evaluation factors to provide detailed information of organizations' environmental performance. The use of these factors is to evaluate the efficiency and effectiveness of environmental aspects as well as significant risks and effects on the environment resulting from organizational activities (CICA, 1994). The evaluation factors can be developed such that they can be assessed or prescribed during an examination of the construction activities, giving practical recommendations for improvements. Such assessments should be consistent and universally applied to most construction projects. It is anticipated that significant environmental improvement will be realized with standardization of quantitative results. Although the importance on the evaluation factors had been defined, in analyzing the relative importance between the evaluation factors is lack to discuss previously.

\section{Research Design}

To achieve the aim of this study as described, a questionnaire survey and interviews are carried out. The targeted respondents are the construction professionals from governmental departments, developers, consultants, main contractors and sub-contractors. They were found 
from the member lists of the Hong Kong Construction Association and Building Contractors complied by the government (HKCA, 2004), approved building contractors’ list from Hong Kong Housing Authority (HKHA, 2004) and other related government websites.

As described, evaluation factors of EPA were summarized from pervious researchers (see Table 1). In order to ensure these factors are applicable to the Hong Kong construction industry, consultations were conducted with six construction practitioners for various types of construction sectors, including government departments, consultants, developers, contractors and sub-contractors. Their comments, which were considered beneficial to this study, were adopted as part of the contents of the questionnaire. Finally, a total of 31 evaluation factors were adopted in the questionnaire (Table 2). Moreover, in order to examine the clarity and effectiveness of the questionnaire, a pilot study was conducted. The questionnaires were reviewed by three construction professionals.

$<$ Table 2>

In the questionnaire, the respondents were asked to choose an appropriate degree of importance for each evaluation factor. A rating scale of 1 (least important) to 7 (most important) was adopted.

In order to validate these findings, confirmatory studies were carried out with twelve construction practitioners from Government departments, environmental consultants, developers, contractors and sub-contractors. Their comments were to be presented in the discussion section. 
In order to verify and show the effectiveness of EPA, three case studies are discussed.

\section{Results}

A total of 377 questionnaires were delivered to the respondents. 114 questionnaires were completed and returned, giving a response rate of 30.24\%. As described, the respondents assessed each evaluation factor in the questionnaires by rating their importance. Principal Component Factor Analysis (PCFA) was performed for the data obtained in this survey. It is a multivariate statistical method condensing a large set of variables or scale items down to a smaller, more manageable number of dimensions or factors. The suitability of the data was first evaluated by examining the Kaiser-Meyer-Olkin (KMO) measure of sampling adequacy. The KMO values obtained for each factor analysis was 0.878 (see Table 3), which was greater than the threshold requirement of 0.50 . It was then grouped the evaluation factors by factor analysis as shown in Table 4.

$<$ Table 3>

$<$ Table 4>

A total of seven factors are extracted in this research. Factor 1 includes "Training to middle level staff”, “Training to frontline staff”, “Training to top managerial staff”, "Management participation”, “Top management support”, “Availability and achievement of environmental policy and objectives and targets" and "Communication channels”. This factor addresses MANAGEMENT AND TRAINING as the most important evaluation factors of EPA. From a statistical point of view, this factor explained about $40 \%$ of variance. Factor 2 consists of "Water sprays for minimizing flying dusts”, “Time management for avoiding generation of noise at restricted hours and close to adjoining noise sensitive parties", "Measures to reduce generation of polluted air" and "Measures to mitigate noise levels". These are described as 
the assessment of the emission of AIR AND NOISE pollutants. Factor 3 includes "Nonconformance received”, “‘Marginal cases put under observation’ received”, “Frequency for specific auditing activities about environmental issues”, "Monitor of corrective actions after auditing” and "Quality of auditing materials”. It is apparent that these are related to the environmental AUDITING of the construction project. "Water reuse or recycle system", "Monitor water usage and promote water conservation", "Waste reuse and recycling", “Chemical wastes treatment and procedures”, "Use of green construction technology” and "Wastewater treatment and procedures" are extracted for Factor 4. This factor is related to the assessment of WASTE AND WATER pollutions in the construction activities. Factor 5 includes “cost-saving on paper”, “cost-saving on timber” and “cost-saving on water”, which concerns the COST-SAVING ON RESOURCES during the construction processes. Factor 6 consists of "Quality of equipment maintenance”, "Monitor of energy consumption” and "Investment on energy". This factor describes the assessment of ENERGY consumptions of construction site. Finally, Factor 7 concerns the compliance of REGULATION regarding the "Complaints / warnings received from governmental body", "Non-compliance records of inspection received from government body" and "Fines and penalties on violation of environmental protections", in which it is considered as the least important factors among them. In sum, the seven factors for EPA were summarized as follows in descending order (factor 1 is the most important factor while factor 7 is the least important factor):

Factor 1: Management and Training

Factor 2: Air and Noise

Factor 3: Auditing

Factor 4: Waste and Water

Factor 5: Cost-saving on Resources 
Factor 6: Energy

Factor 7: Regulation

\section{Discussions}

The identified factors provide a good reference for assessing environmental issues in construction projects. The results obtained from this study suggest that the assessment of management and training is critical for EPA. Indeed, the degree of management participation is important for successful implementation of EPA (Bennett and James, 1999a \& 1999b; Kuhre, 1998). Such participation includes the top (project managers and contract managers), medium (site managers, site engineers, site quality and environmental managers) and frontline (foremen and supervisors) levels of employees. These can improve the overall performances of companies and the outcomes of the construction projects. Getting top management involvement in EPA would lead to the success of such programs. An interviewee explained that support from top management should be received from the very early stage of each process (Kuhre, 1998). For the commitments of top management, they can be shown in many ways, such as approving EPA budget and endorsing proposal. Moreover, the supports of effective training for all employees are necessary under the EPA system for construction organizations (Kuhre, 1998).

Measures of performance on the provision of training to employees will reflect their effectiveness in environmental management. Some organizations, such as the Hong Kong Quality Assurance Agency (HKQAA) and the Hong Kong Productivity Council (HKPC), have introduced a series of environmental related training courses; possible training areas for management, supervisory and site workers are shown in Table 5. Training for top management staff is useful for them to understand the ongoing environmental conditions so 
as to raise their environmental awareness. The training should not simply focus on environmental practices, but also the skills on environmental management of the construction processes. Routine ‘tool-box' training can enhance middle management's environmental knowledge, providing them with practical tools to carry out environmental control as mentioned by one of the interviewees from the large construction organizations. Also, they should acquire the up-to-date knowledge on current development of environmental issues. Furthermore, the training should cover basic information on environmental issues. For those who have lower education background, training should be focused on their actual needs in accordance with their working experience and background.

$<$ Table 5>

The assessment of air and noise pollution is another important factor for EPA. Air pollution is one of the serious problems all over the world. Total suspended particulars have been increasing, which affect the respiratory system, reduce visibility, dirty clothing and buildings, and increase the rate of corrosion. As discussed with the developers and consultants, construction activities generate a lot of dust making significantly polluted the air, thus it is necessary to control the situation by spraying flying dusts and minimizing the generation of polluted air. The high-density building development in Hong Kong makes noise a critical construction challenge (Cole, 2000). On the other hand, noise is an inevitable product during construction work, in which piling is the nosiest activity at construction sites. Different sound power levels generated from powered mechanical equipment are shown in Table 6. Therefore, to reduce their impacts, an effective time management and measurement to noise levels are essential for every construction site.

$<$ Table 6> 
Auditing activities are divided into three stages: pre-auditing, auditing and post-auditing. Construction organizations, which have implemented environmental management, should ensure that all stages of auditing be included so as to ensure a quality output. By providing a periodical audit check during construction, the need for corrective action can be monitored (Jasch, 2000). In the discussions with the interviewees, they pointed out that different auditing process should be involved with various inputs and resources for facilitating the effective and efficient implementation of auditing activities. At the pre-auditing stage, in preparing the factors for the audit plan, consideration should be given to employee level for their ease of understanding on the environmental issues and the organizational documentary system (Jasch, 2000). Quality of the audit factors, rather than the quantity is more important. Therefore, a designated department of the organization should be specifically tasked for preparing an acceptable set of factors for the audit. The number of auditing activities taken place should be included in the evaluation of EPA (Jasch, 2000). The construction organization will normally activate these activities, which are reviewed annually, quarterly, or can be marked as "never take part" in the auditing activities. The environmental performance will be improved if the auditing task is performed more frequently. Actions should be taken to correct the non-conformities in environmental protection, such as 'non-conformance cases' and 'marginal cases put under observation' observed during auditing. Meyer (2001) discovered that from the speed of completion of corrective actions, it could truly reflect the extent of involvement for both management staff and employees in environmental management. For instance, if the completion time of the corrective actions is shortened gradually, this reflects that there is an increase in the number of management and employee's participation in environmental protection.

Generation of polluted water and ineffective use of water are common in construction 
activities. It is necessary to encourage and educate frontline staff to monitor water usage. Water reusing and recycling systems can also be implemented to reduce the usage of water and generation of polluted water. One of the interviewees from a large construction organization explained that water reusing and recycling systems easierly to be implemented by reusing storm-water or construction wastewater for wheel-washing facilities of car-wheel washing and recycling wastewater from wheel washing bay or treatment facilities (HKPC, 2001). Wastewater treatment should be promoted for the final stages before being removed from the construction sites. The amount of waste increases at a rapid rate. According to the Environmental Protection Department (EPD, 2001), the construction industry generated about 32,710 tons of construction and demolition waste in 1998, nearly $15 \%$ above the figure in 1997. Besides the continuous development of economics and infrastructure, people's awareness of waste reduction is always low on sites which also contribute to the problem. With little concern over environmental impacts, excess loss of materials and improper wastes treatment are always common.

In facilitating the on-site activities, paper, timber and water are classified as the three most un-environmentally friendly resources. The production and disposal of these resources directly affect the environment. It is necessary to take all necessary actions to reduce their consumption. As discussed with the sub-contractors, paper can be easily saved and reduced by using double sided copies and online systems; timber can be replaced by steel and aluminum in formwork systems; and water can be saved by using reuse and recycling systems for on-site activities. The long-term cost saving can be gained instead of short-term cost reduction.

Moreover, the operational system includes the operation of the plants and equipment, which 
will encompass the flow of energy (Tibor, 1996). Energy is the main supply to operations, such as operation of the construction plants and temporary lighting system (Bennett and James, 1999b; Jasch, 2000). To evaluate an organization environmental performance, it should understand the consumption of energy in construction activities. In this sense, the monitor of energy usage should be considered. Many aspects of facilities and equipment can influence environmental performance (Bennett and James, 1999b). Each company should provide adequate maintenance for specific construction plants as pointed out by one of the sub-contractors. Regular maintenance of equipment can effectively and directly reduce pollution, including air, noise, waste, and water. For instance, effective maintenance can often be used to dramatically reduce the generation of emissions and help improving operation efficiency (Bennett and James, 1999b).

In the present study, regulatory compliance is not located in high ranking; this indicated that there are some cultural changes in environmental issues of the industry. In fact, the assessment on the number of complaints, non-compliance records and penalties may not encourage the continuous development of environmental protections. The industry now tends to adopt a more positive approach, which places emphasis on managerial issues of the EPA. A voluntary approach has been promoted instead of using traditional mandatory system. Construction organizations have been suggested to implement non-regulatory systems, in which they can gain benefits of long-term cost saving and company images. Representatives from government department explained that there are the best choices for the new environmental trend in the Hong Kong construction industry. 


\section{Verifying and Showing the Effectiveness of the EPA}

Three projects were studied to test the reliability and to show the effectiveness of the developed EPA with seven groups of evaluation factors in measuring the environmental performance for construction. These projects have similar background and were managed by the same experienced environmental manager in a renowned construction organization in Hong Kong. In order to eliminate any variation and inconsistency of results due to deviations of assessment standards, one decision-maker who manages all the three projects is interviewed. Project details are summarized in Table 7, which shows that they are of similar types of development, located in an urban area and with similar contract sums.

$<$ Table 7>

Because of the complexity and the interrelation between the evaluation factors, a scientific method is proposed to determine the weightings of the EPA's factors. A multi-attribute decision making system, called "Non-structural Fuzzy Decision Supporting System" (NSFDSS) (Tam et al., 2002b; 2002c), was proposed. There are three principles in using the non-structural fuzzy decision support system: decomposition, comparative judgment and synthesis of priorities. First, the decomposition principle structures the assessment into elements of different levels, each is independent of those on succeeding levels, and then working downward from the goal (e.g. the overall assessment on performance) on the top through criteria on the second level, and then to sub-criteria on the third level, and so on, working from the general to the more specific at the lower levels. Second, the principle of comparative judgment is applied to construct pair-wise comparisons of the relative importance of criteria on some given levels with respect to the property on their upper level, giving rise to a corresponding matrix. Third principle is the synthesis of priorities. In NSFDSS, priorities are synthesized from the second level downward by multiplying local 
priorities with the priority of their corresponding criterion on an upper level, and weighting each element on the same level according to the factors it affects. (The second-level elements are multiplied by unity, the weight of the single top-level goal.) This gives the composite or global priority of that element, which is then used to weigh the local priorities of the elements on the level below. This procedure is repeated through to the bottom level.

After the manager of these three projects is interviewed for determining the weighting of each evaluation factor of EPA, the results generated by NSFDSS are shown in Table 8. The weighting generated for each evaluation factor in Table 8 is working in line with the results from the last section, which proved the consistency of the importance of the evaluation factors.

$<$ Table $8>$

The manager is then invited to assess the environmental performance of various evaluation factors with significant levels on these three projects. The assessment results generated from EPA are shown in Table 9, with the scores of $67.38 \%, 64.67 \%$ and $63.75 \%$ for Projects 1,2 and 3 respectively. These EPA scores were presented to the environmental manager who concurred with the ranking of the three projects that confirmed the accuracy of EPA.

$<$ Table 9>

Project 1 scores the highest EPA mark. It adopted many precast elements including staircases, slabs, structural beam, which can reduce site material wastage due to site casting. Most of the site activities were carried out within the building envelope to reduce pollution to the nearby buildings. Besides, there were some special measures taken to reduce air, noise and waste pollution on the site. For example, the use of an internal jump lift replacing 
external material hoists can reduce air pollution resulted from the spread of dust. Concrete paved roads were also provided within the site that can reduce the dusty site traffic. Cement was stored independently in huts to reduce waste and prevent airborne dust. In terms of noise pollution control, saw cutting was used instead of concrete breaker during demolition to reduce the generation of noise. Further, all building service installations were prefabricated off-site and ready for use upon delivery. Solid wastes were also sorted on site that facilitated recycling and reuse. The scaffold used was of aluminium scaffolding, which could greatly reduce the consumption of bamboo sticks which would end up in landfills. Furthermore, the project had adopted the Hong Kong Building Environmental Assessment Method (HKBEAM) (HK-BEAM, 1999a; 1999b; 1999c) to assess the environmental design of the building at the planning stage and won an "Excellent" award. The environmental manager observed that middle management had committed themselves in environmental management and the overall environmental performance of the project was satisfactory.

As regards to Projects 2 and 3, the expert commented that Project 2 should perform better as greater dedication to environmental issues from the project team was observed. Project 2 had provided some precautionary measures to reduce pollution, such as movable noise barrier in curtain-form. Construction activities were confined to the time limits of the construction noise permit and an electric poker was chosen for concreting to reduce generation of noise.

Besides, all the three projects had administered an ISO 14001 environmental management system, with a well established wastewater treatment facility, water sprinkler systems on the ground floor and near the exit to reduce airborne dust, waste segregation tanks for inert and non-inert wastes, recyclable corrugated steel sheets to replace timber for subcontractor site sheds and other activities like training policies. All these facilities are to improve the 
environmental performance on site. Currently, more work is in progress and will be reported in the near future.

\section{Conclusion}

EPA is an effective tool to evaluate the environmental conditions at various stages of building construction. However, EPA needs to be quantified by evaluation factors. Seven groups of factors are identified, namely Factor 1: Management and Training; Factor 2: Air and Noise; Factor 3: Auditing; Factor 4: Waste and Water; Factor 5: Cost-saving on Resources; Factor 6: Energy; and Factor 7: Regulation. The results spotlighted the magnitude effects from “Management and Training”. A continuous information support related to environmental issues from the management structure is necessary to enhance employee's environmental awareness. Although construction in Hong Kong indeed is one of the most polluting industries, it is hoped that this will lead the industry to a positive attitude towards using environmental issues and pollution in construction industry can be effectively reduced with the help of using EPA.

\section{Reference}

Bennett, M. and James, P. (1999a) The evolution of integrated environmental performance evaluation and reporting at Baxter international. Sustainable measures: evaluation and reporting of environmental and social performance. Sheffield: Greenleaf publication, pp. 253-282.

Bennett, M. and James, P. (1999b) ISO 14031 and the future of environmental performance evaluation. Sustainable measures: evaluation and reporting of environmental and social performance. Sheffield: Greenleaf publication, pp. 76-97. 
Chen, Z., Li, H. and Wong, T.C. (2000) Environmental management of urban construction projects in China. Journal of Construction Engineering and Management, 126(4), 320324.

CGS (Clayton Group Services) (2001) Homepage, available at http://www.claytongrp.com.

CICA (Canadian Institute of Chartered Accountants) (1994) Reporting on environmental performance. Toronto: Canadian Institute of Chartered Accountants.

Cole, R.J. (2000) Building environmental assessment methods: assessing construction practices. Construction Management and Economics, 18(8), 949-957.

Crawley, D. and Aho, I. (1999) Building environmental assessment methods: applications and development trends. Building Research and Information, 27(4), 300-308.

EPD (Environmental Protection Department) (2001) Hong Kong Environment 2001. Hong Kong Government.

EPD (2004) Homepage, available at http://www.info.gov.hk/epd.

Gottinger, H.W. (1993) Problems of evaluation in environmental project management. Environmental project management: in search of practical approaches to environmental management: proceedings of the International Symposium on Project Management Approach for Environmental Protection, 23-28 February 1986, Pattaya, Thailand, Bangkok: Carl Duisberg Gesellschaft, Southeast Asia Program Office, Asian Institute of Technology, pp. 91-99.

HK-BEAM (Hong Kong Building Environmental Assessment Method) (1999a) An environmental assessment for existing office buildings, Centre of Environmental Technology Limited.

HK-BEAM (1999b) An environmental assessment for new office designs, Centre of Environmental Technology Limited. 
HK-BEAM (1999c) An environmental assessment for new residential buildings, Centre of Environmental Technology Limited.

HKCA (Hong Kong Construction Association) (2004) Homepage, available at http://ww.hkca.com.hk/members.

HKHA (Hong Kong Housing Authority) (2004) Homepage, available at http://www.info.gov.hk/hd/.

HKPC (Hong Kong Productivity Council) (2001) A guide to green construction practices, Hong Kong Special Administration Region.

Jasch, C. (2000) Environmental performance evaluation and indicators. Journal of Cleaner Production, 8(1), 79-88.

Kuhre (1998) ISO 14031--environmental performance evaluation (EPE): practice tools and techniques for conducting an environmental performance evaluation. Upper Saddle River, N.J.: Prentice Hall PTR.

Meyer, R.D. (2001) Conducting environmental performance evaluation using environmental performance indicators. Clayton Group Services.

Morledge, R. and Jackson, F. (2001) Reducing environmental pollution caused by construction plant. Environmental Management and Health, 12(2), 191-206.

Polster, B., Peuportier, B., Sommereux, I.B., Pedregal, P.D., Gobin, C. and Durand, E. (1996) Evaluation of the environmental quality of buildings towards a more environmentally conscious design. Solar Energy, 57(3), 219-230.

Ren, X. (2000) Developing of environmental performance indicators for textile process and product. Journal of Cleaner Production, 8(6), 473-481.

Rikhardsson, P. M. (1999) Information systems for corporate environmental management accounting and performance measurement. Sustainable measures: evaluation and 
reporting of environmental and social performance, Sheffield: Greenleaf publication, pp. 132-150.

Shen, L.Y. and Tam, W.Y.V. (2002) Implementation of environmental management in the Hong Kong construction industry. International Journal of Project Management, 20(7), 535-543.

Tam, W.Y.V., Bao, Q. and Wu, D. (2001) The experience gained in implementing ISO 14000 in Hong Kong construction industry. Proceedings of 2001 CRIOCM International Research Symposium on Development of Construction Management, 17-18 November 2001, Shenzhen University, Shenzhen, China, pp. 99-113.

Tam, C.M., Tam, W.Y.V. and Zeng, S.X. (2002a) Environmental performance evaluation for construction. Building Research and Information, 30(5), 349-361.

Tam, C.M, Tong, K.L., Chiu, C.W. and Fung, W.H. (2002b) Non-structural fuzzy decision support system for evaluation of construction safety management system. International Journal of Project Management, 20(4), 303-313.

Tam, C.M., Tong, K.L. and Chiu, C.W. (2002c) Site Layout Planning using Nonstructural Fuzzy Decision Support System. Journal of construction engineering and management, 128(3), 220-231.

Thoresen, J. (1999) Environmental performance evaluation - a tool for industrial improvement. Journal of Cleaner Production, 7(5), 365-370.

Tibor, T. (1996) ISO 14000: a guide to the new environmental management standards. Chicago: Irwin Professional Publication.

Tse, Y.C.R. (2001) The implementation of EMS in construction firms: case study in Hong Kong. Journal of Environmental Assessment Policy and Management, 3(2), 177-194.

Wathey, D. and O’Reilly, M. (2000) ISO 14031: a practical guide to developing environmental performance indicators for your business. London: Stationery Office. 
Wu, D., Shen, L.Y., Tam, W.Y.V. (2000) Investigation to an alternative for measuring contractor's environmental performance. Proceedings of the International Symposium on Construction Management and Economic Development, 9-12 October 2000, Tianjin, China, pp. 326-334.

Wu, D., Shen, L.Y. and Wang, J.Y. (2001) Multi-hierarchy AHP calculation model for contractor’s environmental performance. Proceedings of 2001 CRIOCM International Research Symposium on Development of Construction Management, 17-18 November 2001, Shenzhen University, Shenzhen, China, pp. 158-176. 
Table 1: A List of Evaluation Factors of EPA from Previous Literature

\begin{tabular}{|c|c|c|c|c|c|c|c|c|}
\hline \multirow{2}{*}{$\begin{array}{l}\text { Evaluation } \\
\text { Factors }\end{array}$} & \multicolumn{8}{|c|}{ Citations } \\
\hline & \begin{tabular}{|l|} 
Rikhardsson \\
(1999)
\end{tabular} & Kuhre (1998) & Jasch (2000) & Wu et al. (2000) & Thoresen (1999) & $\begin{array}{l}\text { Chen et al. } \\
(2000)\end{array}$ & Wu et al. (2001) & $\begin{array}{l}\text { Bennet et al. } \\
\text { (1999b) }\end{array}$ \\
\hline Management & $\mathrm{x}$ & $\mathrm{x}$ & $\mathrm{x}$ & $\mathrm{x}$ & $\mathrm{X}$ & $\mathrm{x}$ & $\mathrm{x}$ & $\mathrm{x}$ \\
\hline $\begin{array}{l}\text { Regulation / } \\
\text { Ordinance }\end{array}$ & $\mathrm{x}$ & $\mathrm{x}$ & $\mathrm{x}$ & & $\mathrm{X}$ & $\mathrm{x}$ & & \\
\hline Training & & $\mathrm{x}$ & $\mathrm{x}$ & & & $\mathrm{x}$ & $\mathrm{x}$ & \\
\hline Feedback & & & $\mathrm{x}$ & & & & & \\
\hline $\begin{array}{l}\text { Materials } \\
\text { Related }\end{array}$ & $\mathrm{x}$ & & $\mathrm{x}$ & $\mathrm{x}$ & & $\mathrm{x}$ & $\mathrm{x}$ & \\
\hline $\begin{array}{l}\text { Financial } \\
\text { Performance }\end{array}$ & $\mathrm{x}$ & $\mathrm{x}$ & $\mathrm{x}$ & & $\mathrm{X}$ & & & $\mathrm{x}$ \\
\hline Site Planning & & & & $\mathrm{x}$ & & $\mathrm{x}$ & & \\
\hline $\begin{array}{l}\text { Communications } \\
\text { and Cooperation }\end{array}$ & & & & $\mathrm{x}$ & & & & \\
\hline Documentation & & $\mathrm{x}$ & & $\mathrm{x}$ & & & $\mathrm{x}$ & \\
\hline $\begin{array}{l}\text { Transport } \\
\text { Planning }\end{array}$ & & & & & $\mathrm{X}$ & & & $\mathrm{x}$ \\
\hline Goal-setting & & $\mathrm{x}$ & & & $\mathrm{X}$ & & & \\
\hline Equipment & & & & & $\mathrm{X}$ & $\mathrm{x}$ & & $\mathrm{X}$ \\
\hline $\begin{array}{l}\text { Waste } \\
\text { Treatment }\end{array}$ & & & & & & & $\mathrm{x}$ & \\
\hline
\end{tabular}




\section{Table 2a: The Identified Evaluation Factors}

\begin{tabular}{|c|c|}
\hline Evaluation Factors & Aim \\
\hline $\begin{array}{l}\text { 1. Complaints/warnings received } \\
\text { from governmental body }\end{array}$ & $\begin{array}{l}\text { To ensure all of the involved construction processes } \\
\text { comply with the regulations and ordinances }\end{array}$ \\
\hline $\begin{array}{l}\text { 2. Non-compliance records of } \\
\text { inspection received from } \\
\text { government body }\end{array}$ & $\begin{array}{l}\text { To ensure all of the involved construction processes are } \\
\text { not affected the human behaviour for nearby sensitive } \\
\text { parties }\end{array}$ \\
\hline $\begin{array}{l}\text { 3. Fines and penalties on violation of } \\
\text { environmental protection }\end{array}$ & $\begin{array}{l}\text { To control the environmental seriousness on on-site } \\
\text { construction activities for those not comply with } \\
\text { regulations and ordinances }\end{array}$ \\
\hline 4. Top management support & $\begin{array}{l}\text { To provide resources in implementing environmental } \\
\text { management from top managerial staff }\end{array}$ \\
\hline 5. Management participation & $\begin{array}{l}\text { To ensure all the organizational staff within the } \\
\text { construction organization are aware in implementing } \\
\text { environmental protection }\end{array}$ \\
\hline 6. Communica & $\begin{array}{l}\text { To conduct regular meetings and channels in } \\
\text { communicate the development of environmental } \\
\text { protection }\end{array}$ \\
\hline $\begin{array}{l}\text { 7. Availability and achievement of } \\
\text { environmental policy, objectives } \\
\text { and targets }\end{array}$ & $\begin{array}{l}\text { To regular review the compliance of company } \\
\text { environmental policy, objectives and targets over the } \\
\text { construction period }\end{array}$ \\
\hline 8. Training to top managerial staff & $\begin{array}{l}\text { e the awareness on environmental issues } \\
\text { anagerial staff }\end{array}$ \\
\hline Ille level staff & $\begin{array}{l}\text { se the awareness on environmental issues } \\
\text { lle level staff }\end{array}$ \\
\hline Traini & $\begin{array}{l}\text { se the awareness on environmental issues } \\
\text { ine staff }\end{array}$ \\
\hline auditing materials & re the sufficiency in the preparation of auditing \\
\hline 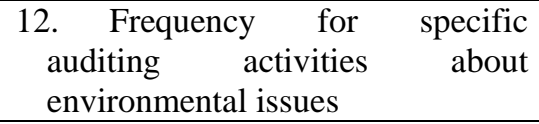 & $\begin{array}{l}\text { To assess the fulfilment on implementing auditing } \\
\text { activities on environmental issues }\end{array}$ \\
\hline 13. Non-conformance received & $\begin{array}{l}\text { To assess the auditing activities in complying } \\
\text { environmental protection }\end{array}$ \\
\hline $\begin{array}{l}\text { 14. "Marginal cases put under } \\
\text { observation” received }\end{array}$ & $\begin{array}{l}\text { To assess the auditing activities in complying } \\
\text { environmental protection }\end{array}$ \\
\hline $\begin{array}{l}\text { 15. Monitor of corrective actions } \\
\text { after auditing }\end{array}$ & the improvements provided after auditing \\
\hline Investment on energy & l investment used on $\mathrm{e}$ \\
\hline $\begin{array}{l}\text { 17. Monitor } \\
\text { consumption }\end{array}$ & he reduction and control of the energy \\
\hline $\begin{array}{l}\text { 18. Quality of equipment } \\
\text { maintenance }\end{array}$ & $\begin{array}{l}\text { To ensure the equipment provided with suitable } \\
\text { maintenance }\end{array}$ \\
\hline Cost-saving on timber & $\begin{array}{l}\text { To assess the performance of cost savings in } \\
\text { consuming timber, such as adopting steel and } \\
\text { aluminum }\end{array}$ \\
\hline Cost-saving on paper & $\begin{array}{l}\text { To assess the performance of cost savings in } \\
\text { consuming paper, such as two-side copy and using } \\
\text { internet }\end{array}$ \\
\hline $\begin{array}{l}\text { 21. Water sprays for minimizing } \\
\text { flying dusts }\end{array}$ & $\begin{array}{l}\text { To ensure the air pollutants emitted outside } \\
\text { construction site by water sprays }\end{array}$ \\
\hline $\begin{array}{l}\text { 22. Measures to reduce } \\
\text { generation of polluted air }\end{array}$ & $\begin{array}{l}\text { To ensure the air pollutant emitted outside construction } \\
\text { site by other means }\end{array}$ \\
\hline
\end{tabular}




\section{Table 2b: The Identified Evaluation Factors}

\begin{tabular}{|c|c|}
\hline Evaluation Factors & Aim \\
\hline $\begin{array}{l}\text { 23. Time management for avoiding } \\
\text { generation of noise at restricted } \\
\text { hours and close to adjoining } \\
\text { noise sensitive parties }\end{array}$ & $\begin{array}{l}\text { To control the generation of noise pollutants at } \\
\text { restricted hours and close to adjoining noise sensitive } \\
\text { parties }\end{array}$ \\
\hline $\begin{array}{l}\text { 24. } \begin{array}{l}\text { Measures to mitigate noise } \\
\text { levels }\end{array} \\
\end{array}$ & $\begin{array}{l}\text { To control the generation of noise pollutants by other } \\
\text { means }\end{array}$ \\
\hline Cost-saving on water & $\begin{array}{l}\text { To assess the performance of cost savings in } \\
\text { consuming water }\end{array}$ \\
\hline $\begin{array}{l}\text { 26. Monitor water usage and } \\
\text { promote water conservation }\end{array}$ & $\begin{array}{l}\text { To control the water consumption in promoting water } \\
\text { conservation }\end{array}$ \\
\hline 27. Water reuse or recycle system & te the water reuse and recycling system \\
\hline $\begin{array}{l}\text { 28. Wastewater treatment and } \\
\text { procedures }\end{array}$ & $\begin{array}{l}\text { To control the cleanliness for wastewater outside } \\
\text { construction site }\end{array}$ \\
\hline $\begin{array}{l}\text { 29. Waste reuse and recycle } \\
\text { system }\end{array}$ & To promote the waste reuse and recycling system \\
\hline $\begin{array}{l}\text { 30. Use of green construction } \\
\text { technology }\end{array}$ & $\begin{array}{l}\text { To promote the adoption on green construction } \\
\text { technology, such as prefabrication }\end{array}$ \\
\hline $\begin{array}{l}\text { 31. Chemical wastes treatment } \\
\text { and procedures }\end{array}$ & $\begin{array}{l}\text { To control the adequate procedures in prep } \\
\text { chemical wastes }\end{array}$ \\
\hline
\end{tabular}


Table 3: Test of data suitability in PCFA

\begin{tabular}{|l|l|l|}
\hline Kaiser-Meyer-Olkin (KMO) measure of sampling adequacy & 0.878 \\
\hline \multirow{3}{*}{ Bartlett Test of Sphericity } & Approx. Chi Square & 2576.424 \\
\cline { 2 - 3 } & Df & 465 \\
\cline { 2 - 3 } & Sig & .000 \\
\hline
\end{tabular}


Table 4: The Overall Results of the PCFA

\begin{tabular}{|c|c|}
\hline \multirow{7}{*}{ Factor 1 : Management and Training } & Training to middle level staff \\
\hline & Training to frontline staff \\
\hline & Training to top managerial staff \\
\hline & Management participation \\
\hline & Top management support \\
\hline & $\begin{array}{l}\text { Availability and achievement of environmental policy, } \\
\text { objectives and targets }\end{array}$ \\
\hline & Communication channels \\
\hline \multirow{4}{*}{ Factor 2 : Air and Noise } & Water sprays for minimizing flying dusts \\
\hline & $\begin{array}{l}\text { Time management for avoiding generation of noise at } \\
\text { restricted hours and close to adjoining noise sensitive parties }\end{array}$ \\
\hline & Measures to reduce generation of polluted air \\
\hline & Measures to mitigate noise levels \\
\hline \multirow{5}{*}{ Factor 3 : Auditing } & Non-conformance received \\
\hline & "Marginal cases put under observation" received \\
\hline & $\begin{array}{l}\text { Frequency for specific auditing activities about environmental } \\
\text { issues }\end{array}$ \\
\hline & Monitor of corrective actions after auditing \\
\hline & Quality of auditing materials \\
\hline \multirow{6}{*}{ Factor 4 : Waste and water } & Water reuse or recycle system \\
\hline & Monitor water usage and promote water conservation \\
\hline & Waste reuse and recycling \\
\hline & Chemical wastes treatment and procedures \\
\hline & Use of green construction technology \\
\hline & Wastewater treatment and procedures \\
\hline \multirow{3}{*}{ Factor 5 : Cost-saving on Resources } & Cost-saving on paper \\
\hline & Cost-saving on timber \\
\hline & Cost-saving on water \\
\hline \multirow{3}{*}{ Factor 6 : Energy } & Quality of equipment maintenance \\
\hline & Monitor of energy consumption \\
\hline & Investment on energy \\
\hline \multirow{3}{*}{ Factor 7 : Regulation } & Complaints / warnings received from governmental body \\
\hline & $\begin{array}{l}\text { Non-compliance records of inspection received from } \\
\text { government body }\end{array}$ \\
\hline & Fines and penalties on violation of environmental protections \\
\hline
\end{tabular}


Table 5: Possible Training Areas for Management, Supervisory and Site Workers (HKPC, 2001)

\begin{tabular}{|l|c|c|c|}
\hline Possible training areas & Management & Supervisory & Site workers \\
\hline Environmental policy & $\sqrt{ }$ & $\sqrt{ }$ & $\sqrt{ }$ \\
\hline $\begin{array}{l}\text { General environmental } \\
\text { awareness }\end{array}$ & $\sqrt{ }$ & $\sqrt{ }$ & \\
\hline $\begin{array}{l}\text { Environmental regulations and } \\
\text { requirements }\end{array}$ & $\sqrt{ }$ & & \\
\hline $\begin{array}{l}\text { Environmental management } \\
\text { system }\end{array}$ & $\sqrt{ }$ & $\sqrt{ }$ & \\
\hline $\begin{array}{l}\text { Environmental programme } \\
\text { establishment }\end{array}$ & $\sqrt{ }$ & $\sqrt{ }$ & \\
\hline $\begin{array}{l}\text { Effective environmental } \\
\text { communication }\end{array}$ & $\sqrt{ }$ & $\sqrt{ }$ \\
\hline License and permit application & & & \\
\hline License and permit conditions & & $\sqrt{ }$ & \\
\hline Good site practices & & $\sqrt{ }$ & \\
\hline $\begin{array}{l}\text { Proper use of equipment and } \\
\text { operational procedures }\end{array}$ & & $\sqrt{ }$ & \\
\hline $\begin{array}{l}\text { Environmental mitigation } \\
\text { measures }\end{array}$ & & $\sqrt{ }$ & \\
\hline $\begin{array}{l}\text { Environmental monitoring and } \\
\text { audit }\end{array}$ & & & \\
\hline Emergency response plan & & & \\
\hline $\begin{array}{l}\text { Green purchasing policy \& } \\
\text { supplier management }\end{array}$ & $\sqrt{ }$ & \\
\hline Sub-contractor management & & & \\
\hline
\end{tabular}


Table 6: Sound Power Level in Powered Mechanical Equipment (HKPC, 2001)

\begin{tabular}{|l|c|}
\hline Powered mechanical equipment & Sound power level (dB(A)) \\
\hline Bulldozer & $110 \mathrm{~dB}(\mathrm{a}) \max$ \\
\hline Breaker (hand-held) & $110 \mathrm{~dB}(\mathrm{a}) \max$ \\
\hline Compressors & $100 \mathrm{~dB}(\mathrm{a}) \max$ \\
\hline Concrete pumps & $105 \mathrm{~dB}(\mathrm{a}) \max$ \\
\hline Dump truck & $109 \mathrm{~dB}(\mathrm{a}) \max$ \\
\hline Excavator & $105 \mathrm{~dB}(\mathrm{a}) \max$ \\
\hline Generator & $100 \mathrm{~dB}(\mathrm{a}) \max$ \\
\hline Lorry & $105 \mathrm{~dB}(\mathrm{a}) \max$ \\
\hline Loader & $105 \mathrm{~dB}(\mathrm{a}) \max$ \\
\hline Poker vibrator & $110 \mathrm{~dB}(\mathrm{a}) \max$ \\
\hline
\end{tabular}


Table 7: Characteristics of Three Sample Projects

\begin{tabular}{|l|l|l|l|}
\hline & Project 1 & Project 2 & Project 3 \\
\hline Nature of project & Superstructure & Superstructure & Superstructure \\
\hline Project type & Commercial & Residential & Residential \\
\hline Sectors & Private & Public & Public \\
\hline Approximate contract sum & HK\$ 400 million & HK\$ 300 million & HK\$ 400 million \\
\hline Contract duration & 20 months & 28 months & 20 months \\
\hline Locations & Urban district & Urban district & Urban district \\
\hline Others & $\begin{array}{l}\text { Assessed by HKBEAM } \\
\text { in the planning stage } \\
\text { (with 'excellent’ } \\
\text { award) }\end{array}$ & - & - \\
\hline
\end{tabular}


Table 8: Weighting for Each Evaluation Factors for EPA

\begin{tabular}{|l|c|}
\hline \multicolumn{1}{|c|}{ Factors } & Weighting (in \%) \\
\hline Factor 1: Management and Training & 22.11 \\
\hline Factor 2: Air and Noise & 19.17 \\
\hline Factor 3: Auditing & 16.70 \\
\hline Factor 4: Waste and Water & 16.46 \\
\hline Factor 5: Cost-saving on Resources & 11.07 \\
\hline Factor 6: Energy & 8.36 \\
\hline Factor 7: Regulation & 6.13 \\
\hline Total & 100.00 \\
\hline
\end{tabular}


Table 9: Environmental Performance Assessment Results of the Three Projects

\begin{tabular}{|l|c|c|c|}
\hline & Project 1 & Project 2 & Project 3 \\
\hline Overall weighting & $67.38 \%$ & $64.67 \%$ & $63.75 \%$ \\
\hline
\end{tabular}




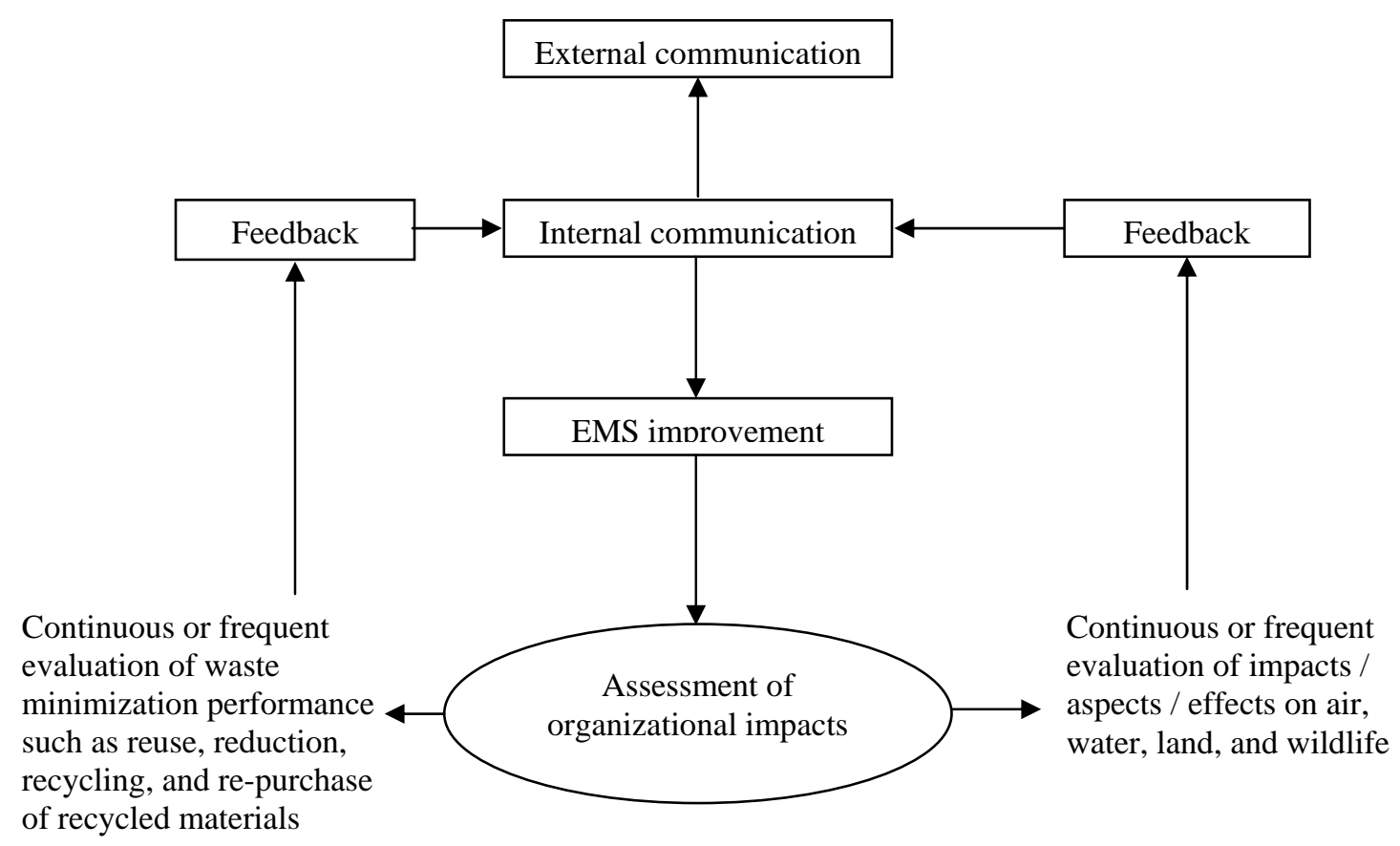

Figure 1: Overview of EPA (Kuhre, 1998) 